\section{APP-045 ラットにおける乳児期エストロゲン暴 露の前立腺発育に及ぼす影響}

富士宮市立病院泌尿器科1), 浜松医大泌尿器科2), 帝国 臓器製薬株式会社川崎事務所 ${ }^{3)}$

海野 智之 ${ }^{17}$, 須床 洋 ${ }^{1)}$, 速水 慎介 ${ }^{2)}$, 石川 晃 ${ }^{23}$, 鈴木 和雄 ${ }^{2 \prime}$, 藤田 公生 ${ }^{2)}$, 大園 誠一郎 ${ }^{21}$, 本間 誠次郎 ${ }^{3 \prime}$ 【目的】前立腺の発育およびその組織構築比には個体差が存在する が、これらの相違は環境因子の関与が大きいと考えられる。我々 は、環境因子の一因として、胎児期ないし乳児期におけるエストロ ゲン暴露がエストロゲンレセプター $(\mathrm{ER} \beta)$ の発現の相違をきたす 可能性について過去に報告した。そこで、今回は ERßの発現の相 違が現れ、前立腺組織構築の相違をもたらす時期について経時的 に検討した。対象・方法】Wistar 系雄性ラットを用い、生誕直後

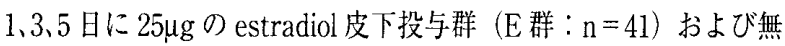
処置対照群 $(\mathrm{N}$ 群： $\mathrm{n}=41)$ に分類した。生後 80、125、160、180日に 屠殺し、前立腺各葉重量/体重比、血中テストステロン、前立腺組 織内テストステロン拉よびDHT、前立腺アンドロゲンレセプター (AR) およびER $\beta$ 発現量、組織構築、PCNA 染色を用いた apoptosisを比較検討した。結果】 80 日ではE 群において腹葉重量比 が有意に低く、125日では $\mathrm{E}$ 群にて血中テストステロン值が有意 に低く、160日では ER 発現の低下および PCNA 染色陽性細胞率 の上昇、組織構築において腺過形成が認められた。考察】ラット乳 児期のエストロゲン暴露は、思春期のテストステロン值低下と青 壮年期の ER $\beta$ 発現低下を来し、したがって ERßによる apoptosis が抑制され、腺過形成をもたらすと考えられた。

\section{APP-046 前立腺肥大症におけるテストステロン と脂質代謝異常}

\section{帝京大学泌尿器科}

武藤 智, 岡田 弘, 堀江 重郎

【目的】脂質代謝異常は前立腺肥大症とともに加龄性疾患 である。また、テストステロン（TST）は加噛により低 下し、その標的臓器の一つが前立腺である。しかし、前 立腺肥大症患者における脂質代謝異常、テストステロン と脂質代謝異常の関係は明らかではない。今回われわれ は、前立腺肥大症患者におけるテストステロンと脂質代 謝異常について検討したので報告する。対象および方 法】対象は前立腺肥大症患者 101 例、年齢は $67.4 \pm 7.8$ 歳。IPSS、尿流量測定を行い、PSA、TST、遊離テス卜 ステロン (free TST)、脂質代謝パラメーターを測定し た。【結果】IPSSはリポプロテイン A ( Lp (a)) (p=0.014) と、最大尿流率 $(\mathrm{Qmax})$ は Lp (a) $(\mathrm{p}=0.034)$ 、free TST $(\mathrm{p}=0.042)$ と有意な相関を示した。またfree TST は年歯 と有意な逆相関を示し $(\mathrm{p}=0.001)$ 、総コレステロール $(\mathrm{p}=0.041) 、$ apoCII $(\mathrm{p}=0.009)$ 、 apoCIII $(\mathrm{p}=0.008)$ と 有意に相関した。結論】今回の検討により、前立腺肥大 症におけるテストステロンと Lp (a)、apoprotein 等の脂 質関連蛋白との関連が示唆された。
APP-047 前立腺の血流調節機構とホルモン（第 4 報）一前立腺血管内皮細胞の分離培 養およびアンドロゲンへの反応

\begin{abstract}
群馬大学大学院医学系研究科器官代謝制御学講座泌尿器 病態学", 帝国臓器メディカル2)

柴田 康博1, 柏木 文蔵", 深堀 能立 ${ }^{1}$, 小野 芳啓", 鈴木 和浩", 本間 誠次郎"2, 山中 英壽"

【目的】前立腺血流調節にはアンドロゲンが関与し、血流制御のシグ ナル伝達には Vascular endothelial growth factor (VEGF) および Nitric oxide (NO) が関与することを明らかにしてきた。血流の調節に は血管内皮細胞が NO synthase (NOS)の産生などの重要な働きをし ていると思われる。しかし、血管内皮紐胞にアンドロゲンレセプター (AR)の存在を示した報告はなく、他の間質細胞を介したパラクライ ン作用や ARを介さない non-genomic な作用の関与が考えられる。 ホルモンによる前立腺血流調節機序の解明にはアンドロゲンや增殖 因子に対する血管内皮練胞の反応を解明することが必要で、ヒ卜前 立腺組織よりの血管内皮細胞分離培養を試みた。方法】手術時に得 られたヒト前立腺細織より血管内皮䋥胞を分離培養し、免疫染色に より綀胞を同定した。培善紐胞に testosteroneを作用させ NOS 活性 の変化を検討した。成績】免疫染色により分離培養細胞は ECであ ることが確認され、高い NOS 活性を示した。 testosterone の添加に より NOS 活性の上昇は認められなかった。結論! ヒ上前立腺組織よ りの血管内皮綀胞の分離培養に成功した。血管内皮細胞単独ではア ンドロゲンの負荷による NOS 活性の上昇はなく、NOを介在する前 立腺血流調節には他の緗胞の関与が必要と思われた。
\end{abstract}

\section{APP-048 前立腺肥大症組織における $\alpha 1 \mathrm{a}$ 受容 体サブタイプと $\alpha 1 \mathrm{~d}$ 受容体サブタイ プの発現量}

\section{名古屋市立大学大学院医学研究科腎 - 泌尿器科学", 国 立成育医療センター研究所菜剤治療研究部 ${ }^{2}$, 京都大学

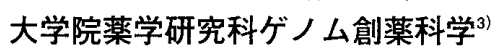

佐々木昌一“", 小島 祥敬”, 林 祐太郎", 郡 健二郎", 篠浦 ひとみ"2), 辻本 豪三”

【目的】これまで前立腺組織に抒ける $\alpha 1$ 受容体は $\alpha$ laが優位に発現し ているとされ、また前立腺肥大症 (BPH) に対する $\alpha 1$ 遮断薬の治寮効 果が患者によって差違があることが報告されている。私達は、患者ごと の遗伝的背景に基づいて、患者間にその発現量に違いがある可能性を仮 定した。そこで定量的RT-PCRを用いて、複数の患者の前立腺組織の $\alpha$ 1 受容体各サブタイプの発現量を測定した。対象と方法」BPH 患者 (35 例: 平均年齢 $67.9 \pm 6.9$ 藏) 亿対し、患者の同意と当施設偷理委貝会承認 のもと、生检時に得られた前立腺組織を用い、定量的 RT-PCR (ABI7700 sequence detector)により $\alpha 1$ 受容体サブタイプ( $\alpha \mathrm{la}$ 、 $\alpha \mathrm{lb} 、 \alpha \mathrm{ld}$ ) mRNA 量を測定した。結果】各サブタイプの発現量の平均值は $\alpha 1 a 、 \alpha 1 b 、 \alpha 1$ d: $2.15 \pm 2.45,0.53 \pm 0.74 、 2.43 \pm 2.56$ copy $/ \beta$-actinであった。 ala $>$ ald の忠者 12 例、 $\alpha 1 \mathrm{la}<\alpha 1 \mathrm{ld}$ の患者 23 例と $\alpha 1 \mathrm{ld}$ 優位の患者の方が多く存在 した。考察]前立腺組織はこれまで $\alpha$ la受容体が優位であるとされてい たが、患者により、 alaが優位な患者と $\alpha$ ld が優位な患者が存在した。 このことは、BPHに対する各種 $\alpha 1$ 交感神経道断薬の治㙩効果に差違が あることの理由のひとつであり、 $\alpha 1$ 受容体サブタイプの発現比率に応 じた治療薬の選択・開発が必要であると考えられた。 